\title{
VARIAÇÕES QUALITATIVAS E QUANTITATIVAS NA MICROBIOTA DO SOLO E NA FIXAÇÃO BIOLÓGICA DO NITROGÊNIO SOB DIFERENTES MANEJOS COM SOJA ${ }^{(1)}$
}

\author{
Alan Alves Pereira ${ }^{(2)}$, Mariangela Hungria ${ }^{(3)}$, Julio Cezar \\ Franchini $^{(3)}$, Glaciela Kaschuk ${ }^{(4)}$, Lígia Maria de Oliveira \\ Chueire $^{(3)}$, Rubens José Campo ${ }^{(3)}$ \& Eleno Torres ${ }^{(3)}$
}

\begin{abstract}
RESUMO
Neste estudo foram avaliados atributos qualitativos e quantitativos da microbiota do solo, visando monitorar alterações por diferentes manejos do solo e das culturas. As avaliações foram feitas em um ensaio a campo, conduzido há 14 anos em Londrina, PR, sob plantio convencional (PC) ou plantio direto (PD) e com sucessão (S) (soja/trigo) ou rotação (R) (tremoço/milho/aveia-preta/soja/trigo/soja/ trigo/soja) de culturas, quando todos os sistemas estavam com soja no estádio de florescimento pleno. Os incrementos no $\mathrm{C}$ e $\mathrm{N}$ da biomassa microbiana (CBM e NBM) no PD foram de 114 e $157 \%$, respectivamente, em comparação ao PC; além disso, o quociente metabólico $\left(q \mathrm{CO}_{2}\right)$ foi inferior em $37 \%$ no PD, indicando maior eficiência metabólica da microbiota do solo. Não foram detectadas diferenças nesses atributos em função dos sistemas de rotação e sucessão de culturas. A diversidade genética da comunidade bacteriana total do solo foi superior no PD e inferior no PC com sucessão de culturas. Em relação à fixação biológica do $\mathrm{N}_{2}$, a massa, o $\mathrm{N}$ total e a fração de $\mathrm{N}$-ureídos acumulados na parte aérea e a eficiência dos nódulos em fixar $\mathrm{N}_{2}$ foram superiores no $\mathrm{PD}$. A diversidade genética dos rizóbios foi afetada, principalmente, pelo manejo das culturas, sendo superior com a rotação, provavelmente pelo maior número de espécies de plantas. Contudo, com a rotação ocorreu decréscimo na eficiência do processo de fixação biológica do $\mathrm{N}_{2}$, o que pode estar relacionado com os teores mais elevados de $\mathrm{N}$ no solo, ou com a menor
\end{abstract}

\footnotetext{
(1) Recebido para publicação em janeiro de 2006 e aprovado em julho 2007.

${ }^{(2)}$ Embrapa Soja, Caixa Postal 231, CEP 86001-970 Londrina (PR). Bolsista de DTI do CNPq. E-mail: alan@cnpso.embrapa.br

(3) Embrapa Soja, Caixa Postal 231, CEP 86001-970 Londrina (PR). E-mails: hungria@cnpso.embrapa.br; franchini@cnpso.embrapa.br; ligia@cnpso.embrapa.br; rjcampo@cnpso.embrapa.br; eleno@cnpso.embrapa.br

${ }^{(4)}$ Doutoranda na Universidade de Wageningen, Holanda. E-mail: glaciela.kaschuk@wur.nl
} 


\begin{abstract}
pressão de seleção por bactérias eficientes. Desse modo, para microrganismos do solo com função específica, como os rizóbios, a diversidade genética pode ser distinta da funcionalidade.
\end{abstract}

Termos de indexação: biomassa microbiana, diversidade genética de bactérias, plantio convencional, plantio direto, rotação de culturas, sucessão de culturas.

\title{
SUMMARY: QUALITATIVE AND QUANTITATIVE CHANGES IN SOIL MICROBIOTA AND BIOLOGICAL NITROGEN FIXATION UNDER DIFFERENT SOYBEANMANAGEMENTS
}

\begin{abstract}
In this study, quantitative and qualitative microbiological parameters were evaluated to detect differences related to soil and crop management. The study was carried out in a field experiment installed 14 years ago on a Rhodic Eutrudox, in Londrina, PR, Brazil. Treatments were a combination of a crop sequence (S) (soybean/wheat) and a crop rotation (R) (lupin/maize/black oat/soybean/wheat/soybean/wheat/soybean), either under conventional tillage (CT) or no-tillage (NT). Evaluations were performed when all systems were under the soybean cropping season, at full flowering. Amounts of microbial biomass carbon and nitrogen (MB-C and MB-N, respectively) were 114 and $157 \%$ higher in NT than in $C T$. Furthermore, the metabolic quotient $\left(\mathrm{qCO}_{2}\right)$ was lower under NT, indicating higher metabolic efficiency of the soil microbes. These parameters were not affected by the crop sequence/rotation. Genetic diversity of the total soil bacterial community was higher under $N T$ and lower in the CT system with crop sequence. Regarding the biological $\mathrm{N}_{2}$ fixation, it was found that plant biomass, total $N$ and fraction of

$N$-ureides in shoots, as well as nodule efficiency, were higher under NT. Genetic diversity of rhizobia was affected mainly by crop management and was higher under crop rotation, probably due to the greater number of plant species. However, crop rotation decreased the efficiency of the biological $N_{2}$ fixation process, which may be related to more abundant $N$ in the soil or to a lower selection pressure for efficient rhizobia. For soil microbes with specific functions, e.g., rhizobia, genetic diversity may therefore differ from functionality.
\end{abstract}

Index terms: microbial biomass, genetic diversity of bacteria; biological nitrogen fixation, conventional tillage, no-tillage; crop rotation, crop sequence, microbial biomass.

\section{INTRODUÇÃO}

Os diferentes manejos do solo e das culturas afetam o equilíbrio existente entre o solo e os organismos que nele habitam, e o sistema de semeadura conhecido como "plantio direto" (PD) tem-se mostrado uma das melhores alternativas conservacionistas para os solos brasileiros. Em 1971, a FUNDACEP/FECOTRIGO, no RS, e o IAPAR, no PR, iniciaram os primeiros ensaios de avaliação da tecnologia do PD (FEBRAPDP, 2006) e, desde então, foram reunidas amplas evidências de que esse sistema resulta em incrementos na retenção de umidade, decréscimo nas temperaturas do solo e controle da erosão do solo e no incremento nos teores de matéria orgânica, resultando em maiores rendimentos das culturas, em comparação com o sistema convencional de preparo do solo (plantio convencional, PC) (Sidiras et al., 1982; Sidiras \& Pavan, 1986; Derpsch et al., 1991; Amado et al., 2001; Sá et al., 2001; Bayer et al., 2002; Castro Filho et al.,
2002). Como resultado, a área sob PD no País incrementou de 2,02 milhões de ha em 1992/93 para cerca de 22 milhões em 2004, abrangendo 50\% de toda a área cultivada para produção de grãos (FEBRAPDP, 2006). Os benefícios do PD podem ser ainda maiores quando associados a rotações de culturas com leguminosas que fixam $\mathrm{N}_{2}$, por exemplo, o trevosubterrâneo (Trifolium subterraneum), a ervilhaca (Vicia sativa), o tremoço (Lupinus spp.), ou outros adubos verdes, como aveia-preta (Avena strigosa) e nabo forrageiro (Raphanus sativus) (Derpsch et al., 1991; Castro Filho et al., 1998; Franchini et al., 2000, 2007).

A atividade dos microrganismos afeta diretamente os atributos químicos e físicos do solo e a meso e macrofauna, contribuindo, ativamente, para sustentabilidade dos sistemas agrícolas. Dentre os fatores limitantes à atividade microbiana estão a disponibilidade de água, energia e nutrientes, a temperatura, a radiação e a distribuição dos agregados 
do solo (Stotzky, 1997; Hungria, 2000). No PD, os macroagregados do solo são mantidos, preservando o hábitat principal dos microrganismos; além disso, ocorre maior disponibilidade de matéria orgânica, fonte de energia e nutrientes para os microrganismos (Colozzi-Filho \& Balota, 1999; Hungria, 2000).

Nos estudos comparativos que foram realizados até o presente momento, no Brasil, em geral foi constatado que a biomassa microbiana é maior em solos sob o sistema PD do que sob PC (Cattelan \& Vidor, 1990; Carvalho, 1997; Cattelan et al., 1997b; Balota et al., 1998, 2003, 2004; Franchini et al., 2007). Ademais, no PR, foi constatado decréscimo no quociente metabólico $\left(q \mathrm{CO}_{2}\right)$ microbiano, que, aliado à maior biomassa, determinaria, a longo prazo, maior acúmulo de $\mathrm{C}$ no solo (Balota et al., 1998, 2004; Franchini et al., 2007). O PD também favoreceu quantitativamente alguns microrganismos de importância agrícola, como bactérias diazotróficas (Ferreira et al., 2000; Hungria, 2000) e fungos micorrízicos arbusculares (Colozzi-Filho \& Balota, 1999). Também foram relatados benefícios na microbiota do solo pela inclusão de leguminosas e, ou, outros adubos verdes no sistema PD (Ferreira et al., 2000; Franchini et al., 2007), embora nem sempre tenham sido constatadas diferenças estatísticas (Balota et al., 1998, 2003). É importante salientar que, com freqüência, os atributos microbiológicos relacionados à microbiota do solo são capazes de detectar alterações pelo manejo do solo e das culturas em um estádio anterior ao das mudanças nos atributos químicos e físicos, levando à proposta de sua utilização como bioindicadores de qualidade do solo (Balota et al., 1998, 2003, 2004; Franchini et al., 2007).

Em relação às alterações qualitativas, no caso de rizóbios microssimbiontes da soja (Glycine max) e do feijoeiro (Phaseolus vulgaris), foi relatada maior diversidade de estirpes em solos sob PD, em comparação com o PC (Ferreira et al., 2000; Hungria et al., 2006a; Kaschuk et al., 2006a,b), havendo relação positiva, inclusive, com o rendimento de grãos (Kaschuk et al., 2006b). Contudo, nem sempre foi verificada maior diversidade de espécies de rizóbios (Kaschuk et al., 2006a), indicando que vários parâmetros precisam ser analisados em conjunto, para evitar conclusões precipitadas. Supõe-se que, em solos com maior biodiversidade, a possibilidade de encontrar classes de microrganismos que atuem em processos importantes, como a degradação de defensivos agrícolas e a manutenção dos processos microbiológicos sob condições de estresse ambiental, entre outros, é maior, representando um "efeito-tampão biológico". Não é clara, porém, a relação entre a biodiversidade e o rendimento da culturas, ou com a sustentabilidade agrícola, principalmente pelo baixo número de informações disponíveis.

Ensaios de longa duração são importantes para definição de atributos estáveis relacionados à sustentabilidade agrícola, bem como para avaliação criteriosa do efeito de diferentes manejos do solo e das culturas nas propriedades químicas, físicas e biológicas do solo. Nesse contexto, procurou-se avaliar, qualitativa e quantitativamente, a microbiota do solo, bem como uma classe de microrganismos utilizada como modelo em nossos estudos, os rizóbios microssimbiontes da soja, em um ensaio estabelecido há 14 anos em Londrina, PR, sob PD ou PC, com rotação ou sucessão de culturas.

\section{MATERIAL E MÉTODOS}

\section{Condução do experimento}

As avaliações foram realizadas em um ensaio estabelecido em 1989 na Estação Experimental da Embrapa Soja ( $23^{\circ} 11^{\prime}$ 'sul, $51^{\circ} 11^{\prime}$ 'oeste e $585 \mathrm{~m}$ de altitude), em Londrina, norte do Paraná, em um Latossolo Vermelho distroférrico eutrófico.

O clima em Londrina é classificado como subtropical úmido, $C f a$, de acordo com a classificação de Köppen. No período de 1976 a 2004, a temperatura média anual no município de Londrina foi de $21,0{ }^{\circ} \mathrm{C}$, com a temperatura média máxima de $27,2^{\circ} \mathrm{C}$ e mínima de $16,6^{\circ} \mathrm{C}$, e a precipitação pluviométrica foi de $1.605 \mathrm{~mm}$. Em janeiro, mês de coleta do ensaio, a temperatura média máxima é de $29,6{ }^{\circ} \mathrm{C}$ e a mínima de $19,6{ }^{\circ} \mathrm{C}$; a pluviosidade média é de 201,6 mm, com 209,7 h de insolação (IAPAR, 2006).

O experimento foi instalado em 1989 e consiste de diferentes manejos de solo, envolvendo aração e gradagem e diferentes rotações e sucessões de culturas; ele é conduzido em blocos ao acaso com quatro repetições, com parcelas de $15 \mathrm{~m}$ de comprimento por $8 \mathrm{~m}$ de largura. Para este estudo, foram consideradas as parcelas sob os sistemas de semeadura conhecidos como plantio direto (PD) (sem revolvimento do solo) e plantio convencional (PC) (com aração e gradagem), com sucessão (S) (trigo - Triticum aestivum/soja Glycine max) ou rotação (R) [tremoço (Lupinus albus)/ milho (Zea mays)/aveia-preta (Avena strigosa)/soja/ trigo/soja/trigo/soja] de culturas.

As coletas de solo e de plantas foram realizadas em janeiro de 2004, quando todas as parcelas estavam com a soja como cultura de verão no estádio R2 (florescimento pleno: $50 \%$ das plantas de cada parcela no estádio de florescimento pleno). A soja era a última cultura da rotação e, no inverno anterior, todas as parcelas estavam com trigo. $\mathrm{Na}$ semeadura, as sementes de soja foram tratadas com inoculante turfoso, contendo as estirpes de Bradyrhizobium elkanii SEMIA 587 e B. japonicum SEMIA 5080 (=CPAC 7), na concentração de 600.000 células/ semente. A inoculação foi realizada conforme descrito anteriormente (Hungria et al., 2006b). A safra de $2003 / 2004$ foi caracterizada por limitada disponibilidade de água [época e precipitação (em mm) efetiva em 2004 e, entre parênteses, precipitação 
normal esperada]: 10/2003-15,4 (156,0); 11/2003$127,8(155,4) ; 12 / 2003-119,6$ (232,00); 01/2004-143,8 (216,4); 02/2004-105,3 (176,8); 03/2004-131,2 (138,3); e 04/2004-66,1 (114,6). As temperaturas médias nessa safra foram [época, temperatura média no ano e, entre parênteses, temperatura média esperada $\left.{ }^{\circ} \mathrm{C}\right]: 10 / 2003$ $21,5(20,7) ; 11 / 2003-22,7(22,1) ; 12 / 2003-23,4(23,1)$; 01/2004-23,2 (23,1); 02/2004-23,4 (24,0); 03/2004-23,1 $(23,4)$; e 04/2004-22,2 (21,2).

As propriedades químicas do solo (camada de 0 $10 \mathrm{~cm}$ ) em 2004 foram avaliadas segundo Pavan et al. (1992) e podem ser visualizadas no quadro 1.

As práticas do experimento, relativas a preparo de solo, adubação, calagem, semeadura, irrigação e controle de plantas invasoras, foram realizadas de modo uniforme em todas as parcelas, conforme as recomendações para as culturas da soja e do trigo no Estado do Paraná, disponibilizadas antes de cada safra (http://www.cnpso.embrapa.br). Os rendimentos foram avaliados na coleta final, com colheita mecânica, em uma área de $3,0 \times 15$ m, correspondente ao tamanho da plataforma da colheitadeira. As sementes foram limpas e pesadas e os valores corrigidos para $13 \%$ de umidade, após determinação do nível de umidade em um determinador de umidade de grãos (Vurroughf 700).

\section{Análises microbiológicas}

Todas as coletas e avaliações foram realizadas em janeiro de 2004.

\section{Avaliações da microbiota do solo \\ Coleta do solo}

De cada uma das parcelas $(15 \times 8 \mathrm{~m}$, quatro repetições) foram coletadas seis subamostras deformadas de solo, da camada de $0-10 \mathrm{~cm}$, nas entrelinhas, utilizando-se uma pá; as amostras foram homogeneizadas e transportadas para o laboratório, onde foram cuidadosamente homogeneizadas, retirando-se restos de raízes ou resíduos vegetais. As amostras foram, então, peneiradas (4 mm, 5 mesh) e armazenadas em saco plástico, dando origem a uma amostra composta. Para análise da biomassa microbiana ( $\mathrm{C}$ e $\mathrm{N}$ da biomassa microbiana e respiração basal) as amostras compostas foram armazenadas por, no máximo, uma semana a $4^{\circ} \mathrm{C} \mathrm{e}$, para análise da diversidade microbiana (item 2.1.5), as amostras foram mantidas a $-70^{\circ} \mathrm{C}$, até o momento das análises.

\section{Carbono e nitrogênio da biomassa microbiana}

Utilizou-se o método de fumigação-extração modificado de Vance et al. (1987) para o C e de Brookes et al. (1985) para o N. Amostras de $20 \mathrm{~g}$ de solo foram fumigadas ou não com clorofórmio $\left(\mathrm{CHCl}_{3}\right)$ isento de álcool, durante a noite (aproximadamente $16 \mathrm{~h}$ ), e o C e $\mathrm{N}$ foram extraídos com sulfato de potássio $\left(\mathrm{K}_{2} \mathrm{SO}_{4}\right)$ $0,25 \mathrm{~mol} \mathrm{~L}^{-1}$. As amostras foram agitadas por $1 \mathrm{~h} \mathrm{a}$ $200 \mathrm{rpm}$, centrifugadas por $10 \mathrm{~min}$ a $2.500 \mathrm{rpm}$ e filtradas em papel qualitativo; os extratos foram congelados, para análise do $\mathrm{C}$ e do $\mathrm{N}$ totais. $\mathrm{O}$ teor de $\mathrm{C}$ nos extratos foi determinado colorimetricamente após oxidação com $\mathrm{Mn}^{3+}$, segundo Bartlett \& Ross (1988), e o teor de $\mathrm{N}$ nas mesmas frações foi determinado por digestão Kjeldahl e determinação colorimétrica do $\mathrm{N}-\mathrm{NH}_{4}$ pelo método de azul de indofenol (Feije \& Anger, 1972). Para os cálculos, utilizou-se um $k_{c}$ de 0,38 para o C (Vance et al., 1987) e um $k_{n}$ de 0,54 para o N (Brookes et al., 1985). Outras três amostras de solo foram coletadas na camada de 0-10 cm e secas a $105^{\circ} \mathrm{C}$, para determinação da densidade aparente do solo (Blake, 1965). Os valores de biomassa microbiana foram corrigidos pela densidade e expressos em $\mu \mathrm{g} \mathrm{g}^{-1}$ de $\mathrm{C}$ ou de $\mathrm{N}$ da biomassa microbiana de solo seco.

\section{Respiração basal}

A respiração foi avaliada pela determinação do C$\mathrm{CO}_{2}$ liberado em amostras não-fumigadas, incubadas

Quadro 1. Propriedades químicas do solo ${ }^{(1)}$ na camada de 0-10 cm, em 2004, no ensaio realizado em Londrina, PR

\begin{tabular}{|c|c|c|c|c|c|c|c|c|c|c|c|c|c|}
\hline $\begin{array}{c}\text { Manejo } \\
\text { solo }^{(2)}\end{array}$ & $\begin{array}{c}\text { Manejo } \\
\text { cultura }^{(3)}\end{array}$ & $\mathrm{pH} \mathrm{CaCl}_{2}$ & $\mathrm{Al}^{3+}$ & $\mathbf{H}+\mathbf{A l}$ & $\mathbf{K}^{+}$ & $\mathrm{Ca}^{2+}$ & $\mathrm{Mg}^{2+}$ & $\mathrm{SB}^{(4)}$ & $\mathrm{CTC}^{(4)}$ & $\mathbf{V}^{(4)}$ & $\mathbf{N}$ & $\mathbf{C}$ & $\mathbf{P}$ \\
\hline & & & \multicolumn{7}{|c|}{$-\mathrm{cmol}_{\mathrm{c}} \mathrm{dm}^{-3}$} & $\%$ & $\underline{-}$ & $\mathrm{g} \mathrm{dm}^{-3}$ & - \\
\hline $\mathrm{PC}$ & $\mathrm{R}$ & 5,11 & 0,01 & 4,06 & 0,67 & 3,76 & 1,45 & 5,88 & 9,94 & 59,0 & 2,10 & 19,47 & 17,8 \\
\hline $\mathrm{PC}$ & $\mathrm{S}$ & 5,41 & 0,00 & 3,69 & 0,60 & 4,86 & 1,83 & 7,28 & 10,98 & 66,4 & 1,54 & 20,62 & 20,6 \\
\hline PD & $\mathrm{R}$ & 5,34 & 0,02 & 4,47 & 0,92 & 4,37 & 1,89 & 7,18 & 11,65 & 61,0 & 2,38 & 22,34 & 36,8 \\
\hline $\mathrm{PD}$ & $\mathrm{S}$ & 5,48 & 0,00 & 3,68 & 0,86 & 5,27 & 2,33 & 8,45 & 12,13 & 69,0 & 2,01 & 23,98 & 40,2 \\
\hline
\end{tabular}

\footnotetext{
(1) Composição física, em $\mathrm{g} \mathrm{kg}^{-1}$ : argila, 710; silte, 82; areia, 208. ${ }^{(2)}$ Sistema de preparo do solo: plantio direto (PD) e plantio convencional (PC). ${ }^{(3)}$ Sistema de manejo das culturas: rotação (R): tremoço/milho/aveia-preta/soja/trigo/soja/trigo/soja; sucessão (S): (trigo/soja). ${ }^{(4)} \mathrm{SB}$ (soma de bases) $=\mathrm{K}^{+}+\mathrm{Ca}^{2+}+\mathrm{Mg}^{2+}$; CTC-pH 7,0 (capacidade de troca de cátions) $=\mathrm{K}^{+}+\mathrm{Ca}^{2+}+\mathrm{Mg}^{2+}+$ $(\mathrm{H}+\mathrm{Al}) ; \mathrm{V}$ (saturação por bases $)=(\mathrm{SB} / \mathrm{CTC} \mathrm{pH} 7) \times 100$.
} 
por 10 dias, e capturando o $\mathrm{CO}_{2}$ em uma solução de hidróxido de sódio $(\mathrm{NaOH})$ 0,5 $\mathrm{mol} \mathrm{L}^{-1}$. Inicialmente, amostras de $20 \mathrm{~g}$ de solo tiveram a umidade corrigida para $24 \%$ da capacidade de campo com água deionizada e foram colocadas em frascos de $300 \mathrm{~mL}$, deixando-se em repouso no escuro por $12 \mathrm{~h}$, em temperatura ambiente. Após esse período, as amostras foram colocadas em recipientes de $2 \mathrm{~L}$ contendo frascos com $\mathrm{NaOH} 0,5 \mathrm{~mol} \mathrm{~L}^{-1}$ e $20 \mathrm{~mL}$ de água, procedendo-se à vedação dos frascos e incubação, no escuro, a $25^{\circ} \mathrm{C}$, por 10 dias. Para cada repetição, foi incubado um frasco sem solo (branco), mas com $\mathrm{NaOH} 0,5 \mathrm{~mol} \mathrm{~L}^{-1}$ e água deionizada. Após o período de incubação, o $\mathrm{NaOH}$ presente nos potes de cada amostra foi titulado com ácido clorídrico ( $\mathrm{HCl}$ ) $0,2 \mathrm{~mol} \mathrm{~L}^{-1}$ padronizado. Os valores de respiração obtidos foram expressos em $\mu \mathrm{g} \mathrm{g}^{-1} \mathrm{dia}^{-1}$ de C-CO ${ }_{2}$ no solo seco.

\section{Quociente metabólico $\left(q \mathrm{CO}_{2}\right)$}

Para obtenção do $q \mathrm{CO}_{2}$, foi feita a divisão da respiração basal pelo $\mathrm{C}$ da biomassa microbiana. Os valores foram expressos em (ng d ${ }^{-1}$ de C- $\mathrm{CO}_{2}$ por $\mu \mathrm{g}$ de C microbiano).

Os dados foram submetidos à análise de variância, usando o programa SAS (SAS, 1999).

\section{Composição bacteriana do solo avaliada em gel desnaturante (DGGE, Denaturating Gradient Gel Electrophoresis)}

Foram utilizadas as amostras de solo de cada parcela, coletadas e compostas, conforme descrito em coleta do solo. Na extração do DNA total do solo foram utilizadas amostras de solo de 0,25 g e o "Ultraclean ${ }^{\mathrm{TM}}$ Soil DNA Kit" (Mobio Laboratories USA), conforme especificações do fabricante. A pureza e concentração do DNA foram avaliadas em um gel de agarose a $1 \%$ em TBE 1X, utilizando como peso-padrão "Low DNA Mass ${ }^{\text {TM" }}$ (Invitrogen-Life Technologies).

Foram realizadas duas reações de amplificação do DNA total do solo para a região que codifica o gene 16S rRNA. Inicialmente, o DNA do solo (20 ng) foi amplificado com os "primers" rD1 e fD1 (15 pmol de cada "primer" por reação), descritos por Weisburg et al. (1991), que amplificam praticamente toda a região do DNA que codifica para o gene $16 \mathrm{~S}$ rRNA $(\sim 1.500$ pares de bases, pb). A amplificação foi realizada usando os seguintes ciclos: um ciclo de desnaturação inicial a $95^{\circ} \mathrm{C}$ por $2 \mathrm{~min}$; 15 ciclos de desnaturação a $94^{\circ} \mathrm{C}$ por $15 \mathrm{~s} ; 93^{\circ} \mathrm{C}$ por $45 \mathrm{~s}$; anelamento dos "primers" a $55^{\circ} \mathrm{C}$ por $45 \mathrm{~s}$; e extensão a $72^{\circ} \mathrm{C}$ por $2 \mathrm{~min}$; a reação foi finalizada com manutenção a $4{ }^{\circ} \mathrm{C}$. Na segunda reação, os produtos da reação (10 ng por reação) foram submetidos a uma nova amplificação, também com "primers" específicos para o $16 \mathrm{~S}$ rRNA, mas codificando uma região menor: "primer" F (5'CGCCCGGGGCGCGCCCCGGGCGGGGCGGGGGCACGGGGGGAACGCGAAGAACCTTAC-3') e R (5'GCGTGTGTACAAGACCC-3') (10 pmol de cada "primer" por reação). A amplificação foi realizada usando os seguintes ciclos: um ciclo de desnaturação inicial a $94{ }^{\circ} \mathrm{C}$ por $2 \mathrm{~min}$; dois ciclos a $94^{\circ} \mathrm{C}$ por $1 \mathrm{~min}$, a $60{ }^{\circ} \mathrm{C}$ por 2 min e a $72^{\circ} \mathrm{C}$ por $2 \mathrm{~min}$; dois ciclos a $94^{\circ} \mathrm{C}$ por $1 \mathrm{~min}$, a $59^{\circ} \mathrm{C}$ por 2 min e a $72^{\circ} \mathrm{C}$ por $2 \mathrm{~min}$; e assim por diante, em ciclos de duas vezes, até atingir a temperatura de anelamento de $55^{\circ} \mathrm{C}$. As reações de amplificação foram realizadas em um termociclador PTC-100 ${ }^{\mathrm{TM}}$ MJ Research, Inc. Os produtos das amplificações foram visualizados por eletroforese em gel de agarose $(1,5 \%, \mathrm{p} / \mathrm{v}),-$ tendo a pureza confirmada - e, então, submetidos à análise de DGGE.

Os produtos das amplificações foram submetidos à eletroforese em um aparato de DGGE (Bio-Rad DCode), no gradiente de 20 a $75 \%$ de uréia, a $100 \mathrm{~V}$, por $16 \mathrm{~h}$, conforme descrito anteriormente (Nogueira et al., 2006). Após a corrida, os géis foram corados com brometo de etídio, fotografados sob radiação UV (302 nm), e as bandas resultantes foram analisadas pelo programa Bionumerics (Applied Mathematics, Kortrijk, Bélgica, v.1.0.1), com nível de tolerância de $3 \%$. Para o agrupamento foi usado o algoritmo UPGMA (Unweighted Pair-Group Method with arithmetic mean, Sneath \& Sokal, 1973) e o coeficiente de Jaccard.

\section{Avaliações envolvendo a simbiose soja- rizóbio \\ População de rizóbios}

A população de rizóbios capazes de nodular a soja foi avaliada pelo método do número mais provável (NMP) com contagem em plantas (Vincent, 1970), utilizando plântulas de soja da cultivar BRS 133. Os resultados foram expressos em número de células $\mathrm{g}^{-1}$ solo seco.

\section{Avaliação da fixação biológica do nitrogênio em soja}

No estádio R2, 20 plantas de soja foram coletadas ao acaso, de cada parcela, evitando-se a área central de estimativa de rendimento, para avaliação da nodulação e do crescimento das plantas. No laboratório, a parte aérea foi separada das raízes, lavada em água destilada e acondicionada em saco de papel. As raízes foram lavadas em água corrente, sobre peneira, e acondicionadas em sacos de papel, juntamente com nódulos porventura caídos na peneira. Todo o material foi colocado em uma estufa a $65^{\circ} \mathrm{C}$, com ventilação forçada, até atingir massa constante (aproximadamente $72 \mathrm{~h}$ ). Os nódulos foram separados das raízes, contados e colocados para secagem novamente, a $65^{\circ} \mathrm{C}$, com ventilação forçada, até atingir massa constante. Procedeu-se à pesagem de todo o material.

Após a pesagem, a parte aérea foi moída em micromoinho, em 20 mesh, para análise dos teores de $\mathrm{N}$ total e de $\mathrm{N}$-ureídos. O N total foi avaliado na parte aérea, conforme descrito anteriormente (Hungria et al., 2006b). A análise do teor de N-ureídos foi feita com base no método de hidrólise seletiva dos ureídos a glioxilato, em pecíolos e folhas de soja coletados em R2 e moídos, segundo Hungria et al. (2006b). 
Os dados foram submetidos à análise de variância (SAS, 1999).

\section{Diversidade genética dos rizóbios}

\section{Isolamento dos rizóbios e do DNA}

$\mathrm{Na}$ análise da diversidade genética dos rizóbios foram utilizados 30 nódulos por parcela, escolhidos ao acaso. No laboratório, procedeu-se ao isolamento e à purificação das bactérias, segundo Vincent (1970). As características morfológicas das bactérias isoladas foram determinadas em meio de cultura com extratode-levedura, manitol e ágar (meio yeast-mannitolagar, YMA, Vincent, 1970) modificado (contendo $5,0 \mathrm{~g} \mathrm{~L}^{-1}$ de manitol- $\mathrm{C}_{6} \mathrm{H}_{14} \mathrm{O}_{6}$ ), com azul de bromotimol $(0,00125 \%)$ como indicador. Para caracterização, foram utilizados os atributos de cor, mucosidade, transparência, bordas, elevação e reação ácida ou básica, definidos por Vincent (1970). Após confirmação da pureza, as bactérias foram armazenadas em meio YM (sem ágar)-modificado com glicerol p.a. (25\%) a $80^{\circ} \mathrm{C}$; as culturas de trabalho foram mantidas em meio YMA-modificado inclinado, a $4^{\circ} \mathrm{C}$. Rotineiramente, as estirpes foram crescidas em YM-modificado, a $28^{\circ} \mathrm{C}$, em um agitador operando a 65 ciclos $\mathrm{min}^{-1}$.

Para extração do DNA, as bactérias foram crescidas em meio YM-modificado a $28^{\circ} \mathrm{C}$, até a concentração de $10^{8}$ células $\mathrm{mL}^{-1}$. Procedeu-se, então, à extração do DNA conforme descrito por Kaschuk et al. (2006b). As amostras foram armazenadas a $-20^{\circ} \mathrm{C}$, para as análises de diversidade.

\section{Diversidade genética de estirpes de rizóbios (BOX-PCR)}

Para detecção da diversidade de estirpes, o DNA das bactérias foi amplificado pela técnica de PCR ("polymerase chain reaction") com o "primer" BOX, que amplifica regiões conservadas e repetitivas do DNA cromossômico, em geral no espaço intergênico, conforme descrito anteriormente (Kaschuk et al., 2006b). Os géis foram corados com brometo de etídeo e fotografados sob radiação UV; as bandas resultantes foram analisadas pelo programa Bionumerics.

\section{Diversidade genética de espécies de rizóbios (RFLP-PCR 16S rRNA)}

Quanto à detecção da diversidade de espécies, procedeu-se à amplificação do DNA (20 ng de cada isolado), pela técnica de PCR com os "primers" rD1 e fD1 (Weisburg et al., 1991) (15 pmol de cada "primer" por reação), conforme descrito por Menna et al. (2006). $\mathrm{O}$ resultado da amplificação foi verificado pela visualização dos fragmentos em gel de agarose de 8 x $10 \mathrm{~cm}$ a 1,5 \%; o padrão de peso molecular utilizado foi o "Low DNA MassTM" (Invitrogen-Life Technologies). Para análise do polimorfismo dos comprimentos dos fragmentos de restrição do DNA (técnica de RFLP, "Restriction Fragment Length Polymorphism"), os produtos de PCR foram digeridos com as seguintes enzimas de restrição: $\mathrm{Hpa}$ II $\left(5^{\prime}-\mathrm{C} /\right.$ CGG-3'; 3'-CGC/C-5'), Hha I (5'-GCG/C-3'; 3'-C/GCG5') e Dde I (5'-C/TNAG-3'; 3'-GANT/C-5') (Invitrogen - Life Technologies) e as análises foram realizadas conforme descrito por Kaschuk et al. (2006a,b). Os géis obtidos foram corados com brometo de etídeo e fotografados sob radiação UV; as bandas resultantes foram analisadas pelo programa Bionumerics, conforme descrito na determinação da composição bacteriana do solo em gel desnaturante.

\section{Índices de diversidade genética}

No cálculo dos índices de diversidade genética dos rizóbios, com base nos perfis obtidos por BOX-PCR e RFLP-PCR, foi considerado o nível de similaridade de $70 \%$, obtido na análise por UPGMA, e o coeficiente de Jaccard; foram considerados como perfis distintos aqueles que apresentavam similaridade inferior a $70 \%$.

A abundância de perfis obtidos nas análises de BOX-PCR e RFLP-PCR em cada categoria de manejo de solo e das culturas foi analisada com o programa SPADE ("Species Prediction and Diversity Estimation") (Chao \& Shen, 2003-2005). A riqueza genética das populações de cada manejo foi calculada com o índice ACE ("abundance-based coverage estimator"), uma estimativa não-paramétrica proposta por Chao \& Lee (1992), na qual as espécies observadas são separadas em dois grupos: raros e abundantes. Nessa análise, somente os indivíduos do grupo raro são usados para estimar o número de indivíduos que estariam faltando na amostragem. $O$ índice de diversidade de Shannon foi calculado com a equação proposta por Shannon \& Weaver (1949), e uma estimativa não-paramétrica do mesmo índice foi baseada no método de cobertura de amostragem e espécies não observadas (Chao \& Shen, 2003). Neste estudo foi considerado o valor de "cut-off" de 4,0. A similaridade entre as comunidades foi avaliada pelo índice de Jaccard (ajustado e não ajustado para considerar espécies não observadas) (Chao et al., 2005), e a predição de novas espécies em um levantamento mais amplo foi estimada conforme recomendado por Shen et al. (2003).

\section{RESULTADOS E DISCUSSÃO}

\section{Avaliações da microbiota do solo \\ Avaliações quantitativas}

$\mathrm{O}$ C e o $\mathrm{N}$ da biomassa microbiana (CBM) e (NBM) foram superiores no plantio direto (PD), tanto no sistema de cultura em sucessão (S) como em rotação (R), quando comparados ao plantio convencional (PC) (Quadro 2), confirmando resultados obtidos anteriormente nos solos do Paraná (Carvalho, 1997; Cattelan et al., 1997b; Balota et al., 1998, 2003, 2004; Franchini et al., 2007). Quando comparado ao PC, o incremento na CBM após 14 anos sob PD foi de $114 \%$, e o da NBM, de $157 \%$. O incremento da biomassa 
microbiana em solos sob PD pode ser atribuído a várias características favoráveis desse sistema: pela manutenção dos macroagregados do solo (Sidiras et al., 1982; Derpsch et al., 1991; Castro-Filho et al., 1998, 2002; Franchini et al., 2000), preservando o nicho principal de atividade dos microrganismos; pelo maior acúmulo de C no solo (Franchini et al., 2000, 2007; Amado et al., 2001; Sá et al., 2001; Bayer et al., 2002), representando maior fonte de energia e nutrientes para os microrganismos; pela redução nas temperaturas máximas e na oscilação de temperaturas do solo (Sidiras \& Pavan, 1986; Derpsch et al., 1991), bem como pela maior retenção de umidade do solo (Sidiras et al., 1982; Derpsch et al., 1991), ambos favorecendo o crescimento e a atividade dos microrganismos.

No PD, houve redução da acidez na camada de 0-10 cm e incremento no teor de nutrientes do solo, com ênfase no P (Quadro 1). Conseqüentemente, a avaliação da microbiota relacionada ao $\mathrm{P}$ deve ser melhor investigada, a fim de estimar sua contribuição. De fato, estímulo nos fungos micorrízicos arbusculares sob PD já foi relatado no Paraná (Colozzi-Filho \& Balota, 1999), bem como na atividade enzimática da fosfatase ácida em um PD conduzido há 21 anos nos Cerrados (Mendes et al., 2003b). Nesse estudo conduzido nos Cerrados, os teores de P também foram superiores no PD, fator atribuído pelos autores ao menor revolvimento no solo, favorecendo a concentração do fósforo trocável na camada superficial.
Nesse caso, a inibição das fosfatases pelo $\mathrm{P}$ seria inferior à do $\mathrm{PC}$, onde os fertilizantes são misturados ao solo. Além disso, apesar de os teores de $\mathrm{P}$ serem mais elevados, a alta afinidade desse nutriente com os colóides organominerais favoreceria a adsorção dos ânions fosfato, reduzindo seu efeito inibidor sobre a atividade da fosfatase (Mendes et al., 2003b).

De grande relevância é considerar que, apesar do incremento expressivo na emissão de $\mathrm{CO}_{2}$ (respiração) e na CBM, o quociente metabólico $\left(q \mathrm{CO}_{2}\right)$ nos solos sob PD há 14 anos foi reduzido em $37 \%$, indicando maior eficiência metabólica da microbiota do solo (Quadro 2). O menor $q \mathrm{CO}_{2}$ contribui, fortemente, para o maior acúmulo de $\mathrm{C}$ no solo com o tempo, conforme também observaram Balota et al. (1998, 2003) e Franchini et al. (2007), em ensaios de longa duração realizados no Paraná. É importante salientar, ainda, que os resultados obtidos neste estudo reforçam que as avaliações da biomassa microbiana podem ser de grande utilidade como bioindicadores da qualidade do solo (Balota et al., 1998; Franchini et al., 2007), pois precedem aquelas constatadas nos métodos tradicionais de avaliação dos teores de matéria orgânica e outras propriedades químicas e físicas do solo.

Em relação ao manejo das culturas, não foram constatadas diferenças estatísticas nos valores de respiração, CBM, NBM e $q \mathrm{CO}_{2}$ (Quadro 2). Tem-se observado, com freqüência, a complexidade da comparação entre diferentes sistemas de cultura,

Quadro 2. Emissão de $\mathrm{CO}_{2}$ (respiração), $\mathrm{C}$ e N da biomassa microbiana (CBM) e (NBM) e quociente metabólico $\left(q \mathrm{CO}_{2}\right)$ em um solo do Paraná há 14 anos sob diferentes manejos do solo e das culturas

\begin{tabular}{|c|c|c|c|c|c|}
\hline Solo ${ }^{(1)}$ & Cultura ${ }^{(2)}$ & Respiração basal & CBM & NBM & $q \mathrm{CO}_{2}$ \\
\hline & & $\begin{array}{l}\mu \mathrm{g} \mathrm{g}^{-1} \mathrm{~d}^{-1} \text { de } \mathrm{C}-\mathrm{CO}_{2} \\
\text { no solo seco }\end{array}$ & $\begin{array}{l}\mu \mathrm{g} \mathrm{g}^{-1} \text { de } \mathrm{C} \text { no } \\
\text { solo seco }\end{array}$ & $\begin{array}{l}\mu \mathrm{g} \mathrm{g}^{-1} \text { de } \mathrm{N} \text { no } \\
\text { solo seco }\end{array}$ & $\begin{array}{c}\text { ng d }{ }^{-1} \mu g^{-1} \text { de } \mathrm{C}-\mathrm{CO}_{2} \text { do } \\
\text { CBM }\end{array}$ \\
\hline \multicolumn{6}{|c|}{ Manejo do solo x manejo das culturas ${ }^{(3)}$} \\
\hline $\mathrm{PC}$ & $\mathrm{R}$ & $1,52 \mathrm{~b}$ & $286,0 \mathrm{~b}$ & $42,1 \mathrm{~b}$ & $5,32 \mathrm{~b}$ \\
\hline $\mathrm{PC}$ & $\mathrm{S}$ & $1,64 \mathrm{~b}$ & $276,2 \mathrm{~b}$ & $40,7 \mathrm{~b}$ & $5,94 \mathrm{~b}$ \\
\hline $\mathrm{PD}$ & $\mathrm{R}$ & $2,09 \mathrm{a}$ & 658,0 a & $102,2 \mathrm{a}$ & $3,18 \mathrm{a}$ \\
\hline $\mathrm{PD}$ & $\mathrm{S}$ & $2,13 \mathrm{a}$ & 547,8 a & 110,8 a & 3,89 a \\
\hline \multicolumn{6}{|c|}{ Manejo do solo ${ }^{(3)}$} \\
\hline $\mathrm{PC}$ & & $1,58 \mathrm{~b}$ & $281,1 \mathrm{~b}$ & $41,4 \mathrm{~b}$ & 5,63 a \\
\hline $\mathrm{PD}$ & & $2,11 \mathrm{a}$ & 602,9 a & $106,5 \mathrm{a}$ & $3,53 \mathrm{~b}$ \\
\hline \multicolumn{6}{|c|}{ Manejo das culturas ${ }^{(3)}$} \\
\hline & $\mathrm{R}$ & $1,80 \mathrm{a}$ & $472,0 \mathrm{a}$ & 72,2 a & $4,25 \mathrm{a}$ \\
\hline & $\mathrm{S}$ & $1,88 \mathrm{a}$ & $412,0 \mathrm{a}$ & 75,8 a & $4,91 \mathrm{a}$ \\
\hline
\end{tabular}

\footnotetext{
(1) Sistema de preparo do solo: plantio direto (PD) e plantio convencional (PC). ${ }^{(2)}$ Sistema de manejo das culturas: rotação (R): tremoço/milho/aveia-preta/soja/trigo/soja/trigo/soja; sucessão (S): (trigo/soja). ${ }^{(3)}$ Médias de quatro (manejo de solo x culturas) ou oito repetições (manejo do solo ou das culturas); valores seguidos pela mesma letra, em cada uma das análises, não diferem estatisticamente ( $p<0,05$, Tukey).
} 
particularmente quando envolvem a soja. Não restam dúvidas sobre os benefícios resultantes de determinadas rotações de culturas, por exemplo, no incremento nos teores de N nos solos pela introdução de leguminosas (Amado et al., 2001; Franchini et al., 2007) ou pelo uso de adubos verdes que favorecem as propriedades físicas do solo, reduzindo a compactação, como a aveia e o nabo forrageiro (Torres \& Saraiva, 1999). Neste estudo, nas parcelas com rotação de culturas houve acréscimo no $\mathrm{pH}$ do solo, mas decréscimo em todos os nutrientes, exceto o $\mathrm{K}$, e, principalmente, incremento nos teores de $\mathrm{N}$, provavelmente ainda um efeito residual do tremoço, quando comparado à sucessão soja/trigo (Quadro 1). A complexidade da introdução de diferentes culturas também foi verificada em outros estudos, onde não houve correlação entre rotação/sucessão de culturas e a biomassa e atividade microbiana do solo (Cattelan et al., 1997a; Balota et al., 1998; Franchini et al., 2007).

\section{Avaliações qualitativas}

Houve pouca variação entre os perfis obtidos nas parcelas de cada tratamento, e, na análise por UPGMA e coeficiente de Jaccard, a similaridade foi superior a $95 \%$, indicando reprodutibilidade e confiança na análise. A figura 1 mostra os perfis representantes de cada tratamento, com evidências de diferenças na diversidade genética, verificando-se menor diversidade no sistema PC com sucessão de culturas. Os sistemas sob PD apresentaram maior diversidade, com destaque para duas bandas de maior intensidade, apontadas com setas na figura 1 . Desse modo, os resultados confirmam que, após 14 anos, os sistemas de manejo do solo e de culturas também afetaram qualitativamente a diversidade da comunidade bacteriana do solo. Recentemente, Peixoto et al. (2006), usando o 16S rRNA como biomarcador na análise de DGGE, constataram apenas diferenças pequenas entre o sistema PD e o PC em Santo Antônio de Goiás, GO. Ainda nesse estudo, as diferenças foram mais claras com o uso de outro marcador, o gene $r p o B$, porém os autores não detectaram diferenças entre rotações de culturas (Peixoto et al., 2006). É possível que, no caso do ensaio realizado em Londrina, as diferenças tenham sido detectadas pelo maior tempo sob distintos sistemas de semeadura e cultivo. É interessante observar, ainda, que Wardle et al. (1997), em um estudo com 32 espécies de plantas, não encontraram evidências de que a riqueza das espécies que compunham os resíduos vegetais fosse importante para o funcionamento do ecossistema, mas sim a presença das espécies vivas. Ao contrário, neste trabalho houve indicação de que, após 14 anos, os resíduos das plantas em rotação afetaram a diversidade da comunidade bacteriana, particularmente no sistema PD.

As bactérias representam apenas uma fração da microbiota do solo e, inclusive, existem indicações de que, na transição do $\mathrm{PC}$ para o PD, ocorre aumento

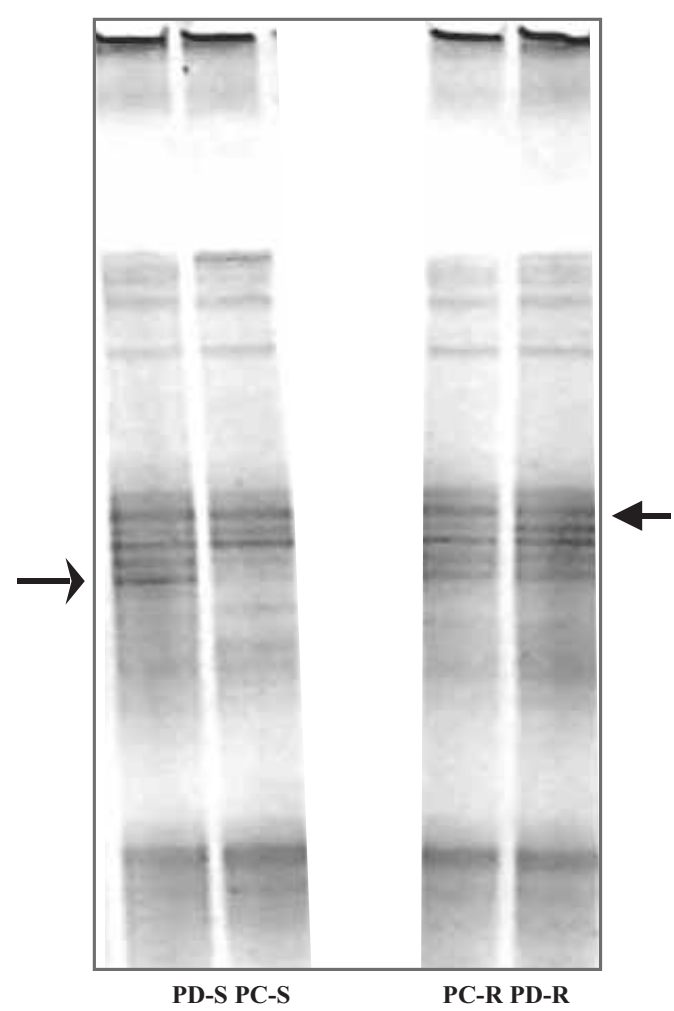

Figura 1. Perfil de DNA total do solo amplificado com "primers" para a região que codifica o gene ribossomal 16S e submetido à análise de DGGE. Solos correspondentes aos seguintes tratamentos: plantio direto (PD), plantio convencional (PC) com sucessão (S: soja/trigo) ou rotação (R: tremoço/milho/aveia-preta/soja/trigo/soja/trigo/ soja) de culturas.

na população de fungos (Hungria, 2000); contudo, os resultados deste estudo indicam coerência entre a BMC, o $q \mathrm{CO}_{2}$ e os perfis obtidos na análise de DGGE. Além disso, fica evidenciado o potencial de utilização de perfis por DGGE como bioindicadores de qualidade do solo. Wellbaum et al. (2004) citam vários trabalhos, realizados em outros países, em que a diversidade microbiana foi incrementada em sistemas com redução de preparo do solo, concluindo que a minimização das operações mecânicas tenderia a maximizar a diversidade microbiana, pela menor ruptura do substrato na cadeia trófica, bem como pela menor dissecação, compactação do solo e melhor adequação do volume de poros.

\section{Simbiose soja-rizóbio}

\section{Avaliação da fixação biológica do $\mathrm{N}_{2}$ e do rendimento da soja}

Não foram detectadas diferenças entre os sistemas de manejo do solo e das culturas na população de rizóbios, e todos apresentaram número de células 
viáveis elevado (Quadro 3). Em outros ensaios de rotação/sucessão de culturas também não foram observadas diferenças no número de células viáveis de rizóbios, exceto pelas sucessões que incluíam apenas gramíneas (Hungria \& Stacey, 1997; Ferreira et al., 2000). O número de nódulos foi superior no PC, mas a massa de nódulos não diferiu entre o PC e o PD; contudo, a massa e o $\mathrm{N}$ total da parte aérea foram superiores no PD. Desse modo, a eficiência dos nódulos foi significativamente superior no $\mathrm{PD}$, em relação ao PC, bem como a contribuição do processo de fixação biológica, avaliada pela fração de $\mathrm{N}$-ureídos. Finalmente, o PD resultou em maior rendimento de grãos (em média, $2.702 \mathrm{~kg} \mathrm{ha}^{-1}$ ), superior em $46 \%$ ao tratamento sob PC (1.847 kg ha-1) (Quadro 3).

Em relação à fixação biológica do $\mathrm{N}_{2}$, já foram relatados, no Paraná, benefícios pela adoção do $\mathrm{PD}$, o qual, quando comparado ao PC, apresentou maior número de células de Rhizobium e Bradyrhizobium (Ferreira et al., 2000; Hungria, 2000), maior acúmulo de flavonóides indutores dos genes da nodulação de Rhizobium e Bradyrhizobium (Hungria \& Stacey, 1997; Hungria, 2000), maior nodulação (Voss \& Sidiras, 1985; Hungria, 2000), maiores taxas de fixação biológica do $\mathrm{N}_{2}$ e, em conseqüência, rendimentos mais elevados (Hungria \& Stacey, 1997; Hungria, 2000; Hungria et al., 2005). Os benefícios devem estar relacionados, em grande parte, ao funcionamento dos nódulos, pelas melhores condições de umidade, aeração e temperatura dos solos; além disso, o sistema pode promover a seleção de bactérias mais eficientes no processo de fixação do $\mathrm{N}_{2}$, conforme indicaram os estudos de Ferreira et al. (2000).

No caso de soja cultivada anualmente ou a cada dois anos, Ferreira et al. (2000) não constataram diferenças na eficiência de rizóbios provenientes de rotação (soja/trigo/milho) ou sucessão (soja/trigo) de culturas, sendo inferior apenas no caso de sucessão com gramínea (trigo/milho). Neste ensaio, também não foram detectadas diferenças significativas, entre os manejos de culturas, em relação à nodulação, bem como na massa, $\mathrm{N}$ total e $\mathrm{N}$-ureídos acumulados na parte aérea e nos rendimentos de grãos $\left(2.204 \mathrm{~kg} \mathrm{ha}^{-1}\right.$ na rotação e $2.345 \mathrm{~kg} \mathrm{ha}^{-1}$ na sucessão), porém a eficiência dos nódulos foi superior com a sucessão de culturas (Quadro 3). Cattelan et al. (1997a) também não observaram diferenças estatísticas no rendimento de grãos em função de diferentes rotações/sucessões de culturas, e as principais diferenças foram obtidas em função dos anos. De fato, incrementos no rendimento em função de rotações de culturas são, em geral, constatados quando todas as culturas são consideradas, em um maior período de tempo (Hungria et al., 2005; Franchini et al., 2007).

\section{Quadro 3. Dados relacionados à fixação biológica do nitrogênio em soja avaliados em R2 e rendimento de grãos no final do ciclo da cultura em função de diferentes manejos do solo e das culturas, em um ensaio conduzido há 14 anos em Londrina, PR}

\begin{tabular}{|c|c|c|c|c|c|c|c|c|c|}
\hline \multirow{2}{*}{ Solo ${ }^{(1)}$} & \multirow{2}{*}{ Cultura ${ }^{(2)}$} & \multirow{2}{*}{$\begin{array}{l}\text { Rizóbio } \\
\text { células } \\
\text { no solo }\end{array}$} & \multicolumn{2}{|c|}{ Nodulação em R2 } & \multicolumn{4}{|c|}{ Parte aérea em R2 } & \multirow{2}{*}{$\begin{array}{l}\text { Rendimento } \\
\text { de grãos }\end{array}$} \\
\hline & & & Número & Massa & Massa & $\mathbf{N}$ total & Eficiência & N-ureído & \\
\hline & & $\mathrm{n}^{\circ} \mathrm{g}^{-1}$ & $\mathrm{n} \%$ planta & $\mathrm{mg} /$ planta & $\mathrm{g} / \mathrm{planta}$ & $\begin{array}{c}\text { mg/planta } \\
\text { de } \mathrm{N}\end{array}$ & $\begin{array}{l}\mathrm{mg} \mathrm{mg}^{-1} \text { de } \mathrm{N} \\
\text { nos nódulos }\end{array}$ & $\%$ & $\mathrm{~kg} \mathrm{ha}^{-1}$ \\
\hline \multicolumn{10}{|c|}{ Manejo do solo x manejo das culturas ${ }^{(3)}$} \\
\hline $\mathrm{PC}$ & $\mathrm{R}$ & $1,094.10^{4}$ & $68,3 \mathrm{ab}$ & $232,2 \mathrm{a}$ & $2,28 \mathrm{c}$ & $80,1 \mathrm{c}$ & $0,34 \mathrm{~b}$ & $79,8 \mathrm{~b}$ & $1.747 \mathrm{~b}$ \\
\hline $\mathrm{PC}$ & $\mathrm{S}$ & $1,115.10^{4}$ & 89,5 a & 269,0 a & $2,57 \mathrm{bc}$ & $98,3 \mathrm{bc}$ & $0,36 \mathrm{~b}$ & $82,4 \mathrm{~b}$ & $1.947 \mathrm{~b}$ \\
\hline $\mathrm{PD}$ & $\mathrm{R}$ & $1,228.10^{4}$ & $44,0 \mathrm{~b}$ & 208,8 a & $2,82 \mathrm{ab}$ & $123,2 \mathrm{ab}$ & $0,59 \mathrm{a}$ & $91,2 \mathrm{a}$ & $2.662 \mathrm{a}$ \\
\hline $\mathrm{PD}$ & $\mathrm{S}$ & $1,115.10^{4}$ & $45,5 \mathrm{~b}$ & $218,5 \mathrm{a}$ & 3,11 a & $150,5 \mathrm{a}$ & $0,69 \mathrm{a}$ & $94,3 \mathrm{a}$ & $2.743 \mathrm{a}$ \\
\hline \multicolumn{10}{|c|}{ Manejo do solo ${ }^{(3)}$} \\
\hline $\mathrm{PC}$ & & & 78,9 a & 250,6 a & $2,42 \mathrm{~b}$ & $89,2 \mathrm{~b}$ & $0,35 \mathrm{~b}$ & $81,1 \mathrm{~b}$ & $1.847 \mathrm{~b}$ \\
\hline $\mathrm{PD}$ & & & $44,8 \mathrm{~b}$ & 213,6 a & 2,96 a & 136,8 a & $0,64 \mathrm{a}$ & 92,8 a & $2.702 \mathrm{a}$ \\
\hline \multicolumn{10}{|c|}{ Manejo das culturas ${ }^{(3)}$} \\
\hline & $\mathrm{R}$ & & 56,2 a & $220,5 \mathrm{a}$ & $2,55 \mathrm{a}$ & $101,6 \mathrm{a}$ & $0,46 \mathrm{~b}$ & 85,5 a & $2.204 \mathrm{a}$ \\
\hline & $\mathrm{S}$ & & $67,5 \mathrm{a}$ & 243,8 a & $2,84 \mathrm{a}$ & $124,4 \mathrm{a}$ & $0,52 \mathrm{a}$ & $88,4 \mathrm{a}$ & $2.345 \mathrm{a}$ \\
\hline
\end{tabular}

(1) Sistema de preparo do solo: plantio direto (PD) e plantio convencional (PC). ${ }^{(2)}$ Sistema de manejo das culturas: rotação (R): tremoço/milho/aveia-preta/soja/trigo/soja/trigo/soja; sucessão (S): (trigo/soja). ${ }^{(3)}$ Médias de quatro (manejo de solo x culturas) ou oito repetições (manejo do solo ou das culturas); valores seguidos pela mesma letra, em cada uma das análises, não diferem estatisticamente $(\mathrm{p}<0,05$, Tukey). 
A fixação biológica do $\mathrm{N}_{2}$ com a cultura da soja, no Brasil, consegue suprir as necessidades da planta em $\mathrm{N}$, permitindo obtenção de alto rendimento; contudo, a simbiose tem-se mostrado extremamente sensível à presença de outras fontes de $\mathrm{N}$ (Hungria et al., 2005, 2006b). Na presença de $\mathrm{N}$ do solo e de $\mathrm{N}$ fertilizantes, ocorre queda acentuada na nodulação da soja; nos estádios posteriores do crescimento da planta, se o suprimento de fontes externas de $\mathrm{N}$ não for mantido, não há tempo hábil de recuperação da nodulação, resultando, inclusive, em menor rendimento de grãos (Mendes et al., 2003a; Hungria et al., 2005, 2006b). Desse modo, rotações de culturas que resultem em maior disponibilidade de $\mathrm{N}$ no solo podem não beneficiar a fixação biológica do $\mathrm{N}_{2}$ com a cultura da soja, conforme foi observado neste (Quadro 3) e em outro estudo (Franchini et al., 2007) realizados em Londrina. As rotações de culturas, portanto, devem ser planejadas para que $\mathrm{o}$ f fornecido pelo adubo verde seja aproveitado por outra cultura com alta demanda de N, como o milho, antes da semeadura da soja.

\section{Diversidade genética de rizóbios}

A amplificação do DNA dos rizóbios com o "primer" específico BOX, relacionado a regiões conservadas e repetidas do DNA, permitiu a deteç̧ão de diversidade genética elevada, com o agrupamento das estirpes em um nível de similaridade bastante baixo, de apenas 24\% (Figura 2). Embora tenham sido observados alguns agrupamentos entre bactérias provenientes de tratamentos sob o mesmo manejo de solo ou de culturas, de modo geral, não houve agrupamentos relacionados aos tratamentos (Figura 2). Laguerre et al. (1997) salientaram que a análise com "primers" de regiões conservadas e repetidas permite a identificação de estirpes, podendo não haver agrupamento de espécies, o que também foi confirmado em outros estudos com rizóbios (Fernandes et al., 2003; Kaschuk et al., 2006a,b). Desse modo, neste estudo, considerando o nível de similaridade de $70 \%$, foram obtidos 42 perfis de BOX-PCR, que corresponderiam a diferentes estirpes (Figura 2).

Considerando cada tratamento e o nível de similaridade de 70\%, no PC-R e PC-S foram observados $23 \mathrm{e}$ 20 perfis de BOX-PCR (Quadro 4), respectivamente, que foram unidos com similaridades finais de 34 e $27 \%$, respectivamente (dados não mostrados). No PD-R e PD-S foram constatados 21 e 16 perfis (Quadro 4), unidos com 39 e $27 \%$ de similaridade final, respectivamente (Figura 3). Nesta figura são mostrados, como exemplo, os dendrogramas obtidos com os rizóbios isolados dos tratamentos PD-R e PD-S, observando-se maior similaridade de isolados na sucessão de culturas.

A diversidade genética de gêneros/espécies de rizóbios foi verificada pela técnica de RFLP-PCR da região do DNA que codifica o gene ribossomal 16S. Na análise com todos os isolados obtidos neste estudo, considerando o nível de $70 \%$ de similaridade, foram constatados 31 perfis (dados não mostrados), número bastante superior ao esperado. No PC-R e no PC-S foram observados 14 e 12 perfis de RFLP-PCR, respectivamente, enquanto no PD-R e no PC-S foram observados 19 e 12 perfis, respectivamente (Quadro 4).

A soja é uma planta exótica, originada da China, que foi introduzida no Brasil provavelmente em 1882, na Bahia, mas o cultivo em larga escala no Paraná iniciou-se apenas na década de 1960. Os solos brasileiros não possuem, originalmente, rizóbios capazes de nodular a soja de modo eficaz, de modo que algumas poucas estirpes foram introduzidas via inoculantes (Hungria et al., 2005, 2006b). Os inoculantes utilizados em Londrina desde a expansão da cultura, nos anos 1960, introduziram um máximo de duas espécies, $B$. japonicum e $B$. elkanii, e 10 estirpes; contudo, a diversidade de estirpes e gêneros/ espécies observada nos isolados de rizóbios deste ensaio foi superior à esperada. Esses resultados podem estar relacionados aos relatos de incremento na diversidade genética de estirpes em função da adaptação aos solos (Santos et al., 1999; Ferreira et al., 2000), inclusive com indicação de transferência lateral de genes simbióticos (Galli-Terasawa et al., 2003; Batista et al., 2007).

Índices de diversidade foram aplicados aos resultados obtidos nas análises por BOX-PCR e RFLPPCR (Quadro 4). A maior diversidade de estirpes de rizóbios (BOX-PCR) seguiu a ordem: $\mathrm{PC}-\mathrm{R}>\mathrm{PD}-\mathrm{R}>\mathrm{PC}$ $\mathrm{S}$, mas com pouca diferença entre os três sistemas, que, por sua vez, apresentaram diversidade consideravelmente superior à do PD-S. A diferença entre o índice de Chao \& Shen (2003) e o de Shannon \& Weaver (1949) reside ao fato de que o segundo desconsidera as possíveis espécies que não foram observadas, ao passo que, no primeiro, esses indivíduos são considerados com base nos grupos raros, que são aqueles que apresentam número inferior ao corte ("cutoff") do modelo. Foi possível, então, verificar, na análise pelo método de Chao \& Shen (2003), que muitos outros genótipos de rizóbios são esperados em um levantamento futuro, particularmente com a rotação de culturas (Quadro 4). Resultados semelhantes foram observados em relação à diversidade de gêneros/espécies de rizóbios (RFLPPCR): $\mathrm{PD}-\mathrm{R}>\mathrm{PC}-\mathrm{R}>\mathrm{PC}-\mathrm{S}>\mathrm{PD}-\mathrm{S}$, também com predição mais elevada de novas espécies nos sistemas com rotação de culturas, pela entrada de maior número de espécies vegetais (Quadro 4).

Os resultados deste estudo confirmam a complexidade dos atributos relacionados à diversidade de microrganismos, pois a maior diversidade genética dos rizóbios (Quadro 4), relacionada à presença de maior número de espécies vegetais em rotação, não foi relacionada à maior eficiência de fixação do nitrogênio (Quadro 3). Ao contrário, o sistema soja/ trigo, no qual o hospedeiro específico, a soja, esteve presente maior número de vezes, resultou em menor diversidade de rizóbios, mas selecionou estirpes mais 


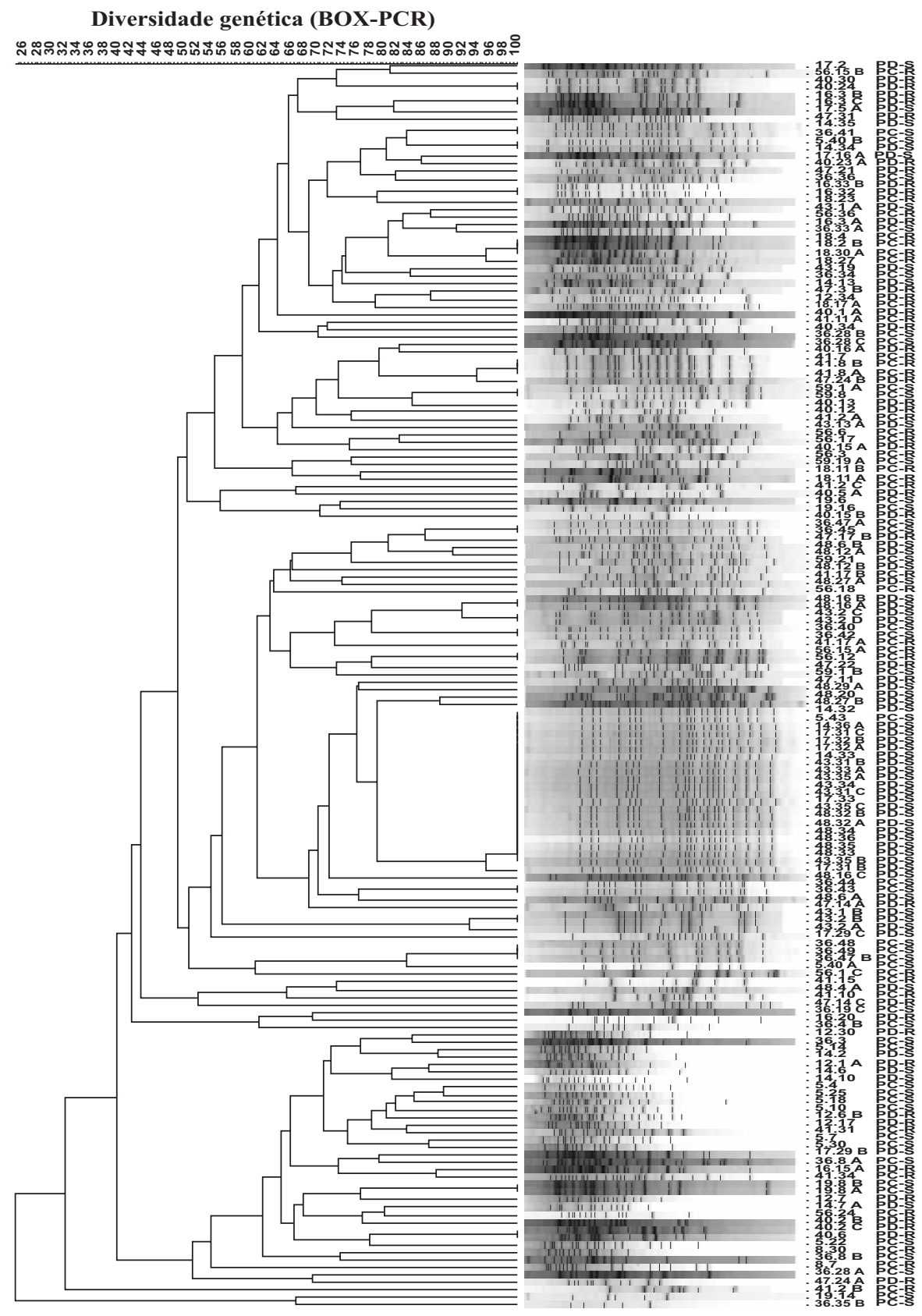

Figura 2. Análise de agrupamento dos produtos obtidos na análise por BOX-PCR do DNA de rizóbios isolados dos nódulos de soja sob diferentes práticas de manejo de solo e das culturas.

eficientes, a fim de garantir o fornecimento adequado de $\mathrm{N}$ à cultura da soja, via fixação biológica.

Ficou evidenciado, portanto, que, no caso de microrganismos específicos, cuja função é o fornecimento de nutrientes às plantas em grande quantidade (portanto, em condições distintas de ecossistemas em equilíbrio), a diversidade pode ser oposta à funcionalidade. Resultados semelhantes foram relatados, recentemente, para a população de rizóbios microssimbiontes do feijoeiro (Phaseolus vulgaris), quando áreas nativas dos Cerrados foram comparadas com áreas incorporadas à agricultura (Grange, 2005). Ainda nesse contexto, essas observações também encontram respaldo nos resultados de Hungria et al. (2001, 2006a), que verificaram que os rizóbios de solos sob PC apresentavam maior diversidade fisiológica em relação ao metabolismo de diferentes fontes de C, mas menor diversidade genética e na capacidade de fixação de $\mathrm{N}_{2}$, enquanto o oposto era observado para os isolados de solos sob PD. Com isso, esses autores constataram que, na presença de maior quantidade de C, particularmente fontes de assimilação mais fácil em 
Quadro 4. Índices de diversidade genética ${ }^{(1)}$, estimados pelos perfis de BOX-PCR e de RFLP-PCR da região do DNA que codifica o gene 16S rRNA, de rizóbios isolados de nódulos de soja sob diferentes manejos de solo e de culturas

\begin{tabular}{|c|c|c|c|c|}
\hline Índice de diversidade & $\mathbf{P C}-\mathbf{R}^{(2)}$ & $\mathbf{P C}-\mathbf{S}^{(2)}$ & PD- $\mathbf{R}^{(2)}$ & PD-S $\mathbf{S}^{(2)}$ \\
\hline & \multicolumn{4}{|c|}{ BOX-PCR } \\
\hline Shannon tradicional & $2,925 \pm 0,123$ & $2,778 \pm 0,104$ & $2,861 \pm 0,102$ & $1,992 \pm 0,181$ \\
\hline Shannon modificado & $3,715 \pm 0,390$ & $3,144 \pm 0,190$ & $3,381 \pm 0,236$ & $2,335 \pm 0,358$ \\
\hline Riqueza genética(ACE) & $90,6 \pm 43,0$ & $30,2 \pm \quad 7,4$ & $43,9 \pm 15,3$ & $26,4 \pm 8,6$ \\
\hline Genótipos observados & 23 & 20 & 21 & 16 \\
\hline Cobertura estimada da amostragem & 0,471 & 0,791 & 0,611 & 0,830 \\
\hline Homogeneidade da amostragem & 1.044 & 0.655 & 0.647 & 1.952 \\
\hline \multirow[t]{2}{*}{$\begin{array}{l}\text { Predição de novos genótipos em um } \\
\text { levantamento futuro }{ }^{(3)}\end{array}$} & $63,1 \pm 42,4$ & $12,6 \pm$ & $55,9 \pm$ & $44,0 \pm 7,4$ \\
\hline & \multicolumn{4}{|c|}{ RFLP-PCR } \\
\hline Shannon tradicional & $2,327 \pm 0,151$ & $2,357 \pm 0,086$ & $2,677 \pm 0,139$ & $2,176 \pm 0,128$ \\
\hline Shannon modificado & $2,764 \pm 0,298$ & $2,593 \pm 0,123$ & $3,299 \pm 0,351$ & $2,453 \pm 0,209$ \\
\hline Riqueza genética(ACE) & $34,0 \pm 15,5$ & $13,9 \pm 1,9$ & $63,1 \pm 30,0$ & $21,7 \pm 8,7$ \\
\hline Genótipos observados & 14 & 12 & 19 & 12 \\
\hline Cobertura estimada da amostragem & 0,690 & 0,862 & 0,563 & 0,781 \\
\hline Homogeneidade da amostragem & 1,025 & 0,000 & 1,086 & 0,839 \\
\hline $\begin{array}{l}\text { Predição de novos genótipos em um } \\
\text { levantamento futuro }\end{array}$ & $45,0 \pm 52,8$ & $6,0 \pm$ & $56,0 \pm 43,9$ & $36,7 \pm 44,8$ \\
\hline
\end{tabular}

\footnotetext{
${ }^{(1)}$ Valores encontrados \pm erro-padrão da média. ${ }^{(2)}$ Sistema de manejo das culturas: rotação (R): tremoço/milho/aveia-preta/soja/ trigo/soja/trigo/soja; sucessão (S): (trigo/soja). ${ }^{(3)}$ Parâmetros definidos: $\mathrm{m}=1000$ (tamanho da amostragem) e $k=4$ (valor de corte, "cut-off").
}

solos sob PD, deixou de existir pressão de seleção nos rizóbios para utilização de diferentes fontes de $\mathrm{C}$ e que, com a maior demanda de $\mathrm{N}$ pelas plantas, houve pressão de seleção para fixação do $\mathrm{N}_{2}$. Conseqüentemente, a maior diversidade fisiológica ou genética de alguns microrganismos pode não estar associada com a melhor funcionalidade em termos de necessidades das culturas. Kaschuk et al. (2006a,b) também salientaram a importância de avaliar diversos atributos microbiológicos, dada a complexidade das interações microbianas nos diversos sistemas agrícolas, visando evitar interpretações errôneas, o que também fica evidenciado pelos resultados deste trabalho.

\section{Microbiota do solo e a sustentabilidade de sistemas agrícolas com soja}

Estudos de longo prazo da Embrapa Soja têm demonstrado que o PD pode apresentar produtividade igual ou inferior à do $\mathrm{PC}$ nos primeiros quatro a seis anos de adoção, período a partir do qual as produtividades passam a ser sempre superiores no PD (Saraiva et al., 2002; Hungria et al., 2005). É provável que as produtividades, no período inicial, estejam relacionadas à ordenação das culturas, à cobertura do solo e, conseqüentemente, ao período necessário para que haja o acúmulo de material orgânico em quantidade suficiente para alterar as propriedades físicas (resistência do solo ao desenvolvimento radicular, estabilidade estrutural e porosidade), químicas (disponibilidade e distribuição de nutrientes) e biológicas (relação entre macrofauna benéfica e pragas, biomassa microbiana, doenças e plantas daninhas) do solo. Os conhecimentos acumulados nesses anos sobre o PD estão permitindo incrementos no rendimento das culturas já a partir dos primeiros anos de estabelecimento do sistema (Hungria et al., 2006b). Contudo, é importante considerar que a produtividade das culturas representa um parâmetro complexo, muitas vezes afetado por condições climáticas ou doenças, e, portanto, não reflete necessariamente a qualidade ou sustentabilidade do solo. Isso explica por que, nem sempre, a CBM apresenta correlação com o rendimento de grãos (Cattelan et al., 1997a,b). É possível que, neste trabalho, a correlação entre a CBM e o rendimento das culturas, apesar das condições climáticas não favoráveis nessa safra, se deva à maior estabilidade do sistema de PD, estabelecido ao longo dos 14 anos, pois com o tempo as diferenças acumulativas suplantam diferenças pontuais.

A complexidade dos sistemas de rotação e sucessão de culturas também foi demonstrada neste estudo e deve estar relacionada a diversos fatores, como composição dos restos culturais, tempo de permanência dos resíduos na superfície do solo, tempo necessário para decomposição dos resíduos, entre outros (Franchini et al., 2002, 2003, 2007). Desse modo, a 
Diversidade genética (BOX-PCR) - PD com rotação
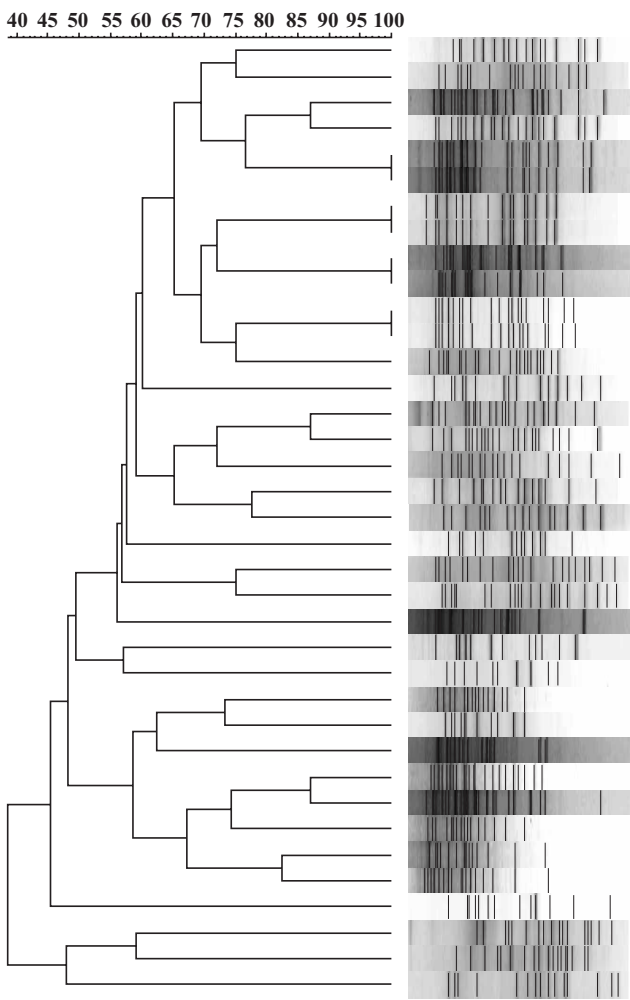

Diversidade genética (BOX-PCR) - PD com sucessão 404550556065707580859095100

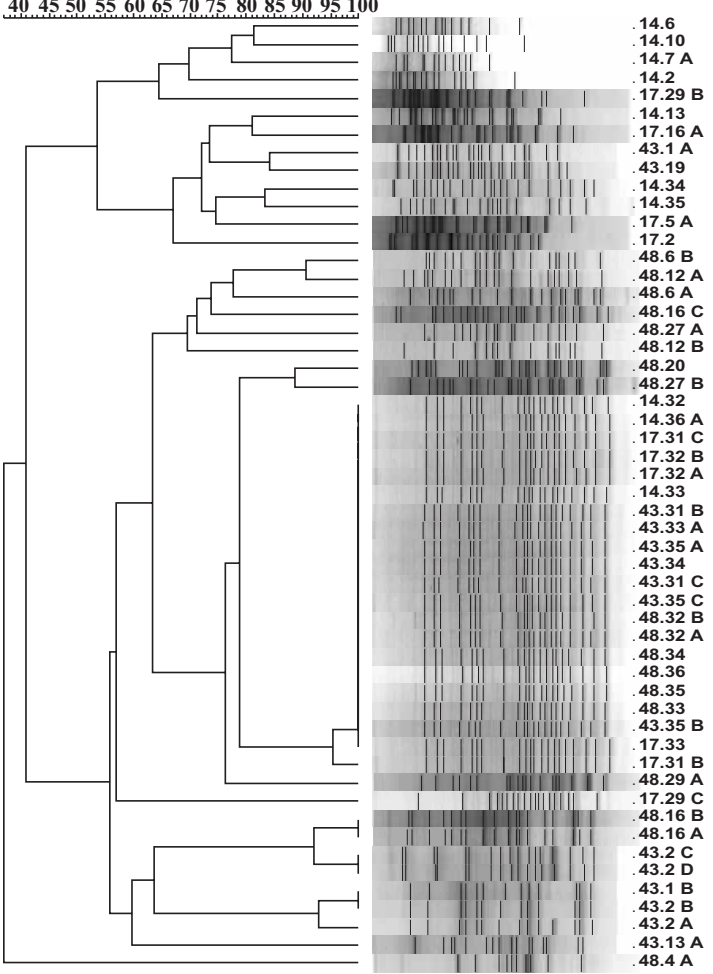

Figura 3. Análise de agrupamento dos produtos obtidos na análise de BOX-PCR do DNA de rizóbios isolados dos nódulos de soja sob os sistemas plantio direto (PD) com rotação (tremoço/milho/aveia-preta/soja/trigo/soja/trigo/ soja) ou sucessão (soja/trigo) de culturas. ordenação correta das espécies dentro dos sistemas de rotação de culturas e o entendimento da decomposição dos resíduos das culturas, bem como do efeito destes na temperatura do solo, na disponibilidade de água e na composição da matéria orgânica, são essenciais para o delineamento de estratégias visando à sustentabilidade dos agroecossistemas. Outra hipótese é de que maior número de espécies pode ser necessário para reduzir a variabilidade temporal nos processos que ocorrem em ecossistemas que não estão em equilíbrio (Loreau et al., 2001). Contudo, os resultados aqui obtidos indicam a necessidade de melhorar as estratégias de manejo dos resíduos culturais para garantir maiores rendimentos, especialmente quando os sistemas incluem a soja.

Alguns estudos realizados principalmente em regiões temperadas apontaram limitações no uso do $q \mathrm{CO} 2$ e da biomassa microbiana para avaliar o efeito do impacto agrícola ou de estresses ambientais (Wardle \& Ghani, 1995; Wardle et al., 1999). No entanto, os resultados obtidos neste estudo, em adição aqueles relatados por Balota et al. (1998) e Franchini et al. (2007), evidenciam o potencial de utilização dos atributos de CBM e de $q \mathrm{CO}_{2}$ como bioindicadores de qualidade do solo e da sustentabilidade agrícola. $\mathrm{O}$ $q \mathrm{CO}_{2}$ também foi o melhor indicador, juntamente com a densidade do solo, em outro estudo realizado na microbacia hidrográfica do Rio Passo Cue, Itaipu, região oeste do Paraná (Leonardo, 2003). É importante salientar, ainda, que as diferenças relacionadas ao manejo dos solos nos estudos realizados no Paraná (Carvalho, 1997; Balota et al., 1998; Leonardo, 2003; Franchini et al., 2007) são de magnitude superior às relatadas em regiões temperadas (Wardle \& Ghani, 1995; Wardle et al., 1997, 1999), enfatizando a rapidez com que os processos microbiológicos ocorrem nos solos tropicais.

Este estudo também evidenciou o potencial de utilização de atributos relacionados à diversidade genética total da microbiota do solo como bioindicadores de qualidade do solo. Já a NBM não se mostrou tão efetiva quanto a CBM, provavelmente por incluir microrganismos funcionais que atuam no complexo ciclo do $\mathrm{N}$; provavelmente, o mesmo possa ocorrer, em sistemas que não estão em equilíbrio (sistemas agrícolas), com o $\mathrm{P}$ e o $\mathrm{S}$ da biomassa microbiana.

\section{CONCLUSÕES}

1. Valores superiores do $\mathrm{C}$ da biomassa microbiana (CBM) e de diversidade genética da comunidade bacteriana total do solo e inferiores de quociente metabólico microbiano $\left(q \mathrm{CO}_{2}\right)$ foram associados com o plantio direto e com a rotação de culturas, em comparação com o plantio convencional e a sucessão de culturas, respectivamente. 
2. No caso de microrganismos do solo com função específica, como os rizóbios simbiontes de soja, responsáveis pelo fornecimento de $\mathrm{N}$ às plantas em grande quantidade (portanto, em condições distintas de ecossistemas em equilíbrio), a maior diversidade genética não foi relacionada à funcionalidade, em termos de maior capacidade de fixação de $\mathrm{N}_{2}$.

\section{AGRADECIMENTOS}

Projeto parcialmente financiado pela Fundação Araucária (convênio 046/2003) e pelo MCT/CNPq/ PRONEX/Instituto do Milênio. Os autores agradecem a Fernando G. Barcellos, Fabio Plotegher, Rinaldo Benedito Conceição, Pâmela Menna e Fábio L. Mostasso (Embrapa Soja), pelo auxílio em várias etapas deste estudo. M. Hungria (301241/2004-0) e L.M.O. Chueire (360924/2004-2) são também bolsistas do CNPq, e G. Kaschuk é bolsista de doutorado da CAPES (2694/04-2).

\section{LITERATURA CITADA}

AMADO, T.J.C.; BAYER, C.; ELTZ, F.L.F. \& BRUM, A.C.R Potencial de culturas de cobertura em acumular carbono e nitrogênio no solo no plantio direto e a melhoria da qualidade ambiental. R. Bras. Ci. Solo, 25:189-197, 2001.

BALOTA, E.L.; ANDRADE, D.S.; COLOZZI FILHO, A. \& DICK, R.P. Microbial biomass in soils under different tillage and crop rotation systems. Biol. Fert. Soils, 38:15-20, 2003.

BALOTA, E.L.; COLOZZI FILHO, A.; ANDRADE, D.S. \& DICK, R.P. Long-term tillage and crop rotation effects on microbial biomass and $\mathrm{C}$ and $\mathrm{N}$ mineralization. Soil Till. Res., 77:137-145, 2004.

BALOTA, E.L.; COLOZZI-FILHO, A.; ANDRADE, D.S. \& HUNGRIA, M. Biomassa microbiana e sua atividade em solos sob diferentes sistemas de preparo e sucessão de culturas. R. Bras. Ci. Solo, 22:641-649, 1998.

BARTLETT, R.J. \& ROSS, D.N. Colorimetric determination of oxidizable carbon in acid soil solutions. Soil Sci. Soc. Am. J., 52:1191-1192, 1998.

BATISTA, J.S.S.; HUNGRIA, M.; BARCELLOS, F.G.; FERREIRA, M.C. \& MENDES, I.C. Variability in Bradyrhizobium japonicum and B. elkanii seven years after introduction of both the exotic microsymbiont and the soybean host in a Cerrados soil. Microbiol. Ecol., 53:270-284, 2007.

BAYER, C.; MIELNICZUK, J.; MARTIN-NETO, L. \& ERNANI, P.R. Stocks and humification degree of organic matter fractions as affected by no-tillage on a subtropical soil. Plant Soil, 238:133-140, 2002.

BLAKE, G.R. Bulk density. In: BLACK, C.A., ed. Methods of soil analysis, Madison, Wisconsin, American Society of Agronomy, 1965. Part 2. p.374-390.
BROOKES, P.C.; LANDMAN, A.; PRUDEN, G. \& JENKINSON, D.S. Chloroform fumigation and the release of soil nitrogen: A rapid direct extraction method to measure microbial biomass nitrogen in soil. Soil Biol. Biochem., 17:837-842, 1985.

CARVALHO, Y. Densidade e atividade dos microrganismos do solo em plantio direto e convencional, na região de Carambeí - PR. Curitiba, Universidade Federal do Paraná, 1997. 108p. (Tese de Mestrado)

CASTRO FILHO, C.; LOURENÇO, A.; GUIMARÃES, M.F. \& FONSECA, I.C.B. Aggregate stability under diferent soil management systems in a red Latosol in the state of Parana, Brazil. Soil Till. Res., 65:45-51, 2002.

CASTRO FILHO, C.; MUZILLI, O. \& PODANOSCHI, A.L. Estabilidade de agregados e sua relação com o teor de carbono num Latossolo Roxo Distrófico, em função de sistemas de plantio, rotação de culturas e métodos de preparo das amostras. R. Bras. Ci. Solo, 22:527-538, 1998.

CATTELAN, A.J. \& VIDOR. C. Sistemas de culturas e a população microbiana do solo. R. Bras. Ci. Solo, 14:125132,1990

CATTELAN, A.J.; GAUDÊNCIO, C.A. \& SILVA, T.A. Sistemas de culturas em plantio direto e os microrganismos do solo, na cultura da soja, em Londrina. R. Bras. Ci. Solo, 21:293-301, 1997a.

CATTELAN, A.J.; TORRES, E. \& SPOLADORI, C.L. Sistemas de preparo com a sucessão trigo/soja e os microrganismos do solo em Londrina. R. Bras. Ci. Solo, 21:303-311, 1997b.

CHAO, A. \& LEE, S.M. Estimating the number of classes via sample coverage. J. Am. Sta. Assoc., 87:210-217, 1992.

CHAO, A. \& SHEN, T.J. Nonparametric estimation of Shannon's index of diversity when there are unseen species in sample. Environ. Ecol. Stat., 10:429-443, 2003.

CHAO, A. \& SHEN, T.J. Program SPADE (Species Prediction And Diversity Estimation). Program and user's guide. (2003- 2005) Disponível em: <http://chao.stat.nthu.edu.tw>

CHAO, A.; CHAZDON, R.L.; COLWELL, R.K. \& SHEN, T.J. A new statistical approach for assessing similarity of species composition with incidence and abundance data. Ecol. Letters, 8:148-159, 2005.

COLOZZI-FILHO, A. \& BALOTA, E.L. Plantio direto: Microrganismos e processos. In: SIQUEIRA, J.O.; MOREIRA, F.M.S.; LOPES, A.S.; GUILHERME, L.R.; FAQUIN, V.; FURTINNI, A.E. \& CARVALHO, J.G., eds. Soil fertility, soil biology and plant nutrition interrelationships. Lavras, SBCS/UFLA/DCS, 1999. p.487508.

DERPSCH, R.; ROTH, C.H.; SIDIRAS, N. \& KOPKE, U. Controle da erosão no Paraná, Brasil: Sistemas de cobertura do solo, plantio direto e preparo conservacionista do solo. Eschborn, Londrina, GTZIAPAR, 1991. 272p.

FEDERAÇÃO BRASILEIRA DE PLANTIO DIRETO NA PALHA - FEBRAPDP. Disponível em: <http:/ www.febrapdp.org.br/>. Acesso em: 28 mar. de 2006. 
FEIJE, F. \& ANGER, V. Spot test in inorganic analysis. Anal. Chem. Acta, 149:363-367, 1972.

FERNANDES, M.F.; FERNANDES, R.P.M. \& HUNGRIA, M. Caracterização genética de rizóbios nativos dos tabuleiros costeiros eficientes em culturas do guandu e caupi. Pesq. Agropec. Bras., 38:911-920, 2003.

FERREIRA, M.C.; ANDRADE, D.S.; CHUEIRE, L.M.O.; TAKEMURA, S.M. \& HUNGRIA, M. Effects of tillage method and crop rotation on the population sizes and diversity of bradryhizobia nodulating soybean. Soil Biol. Biochem., 32:627-637, 2000.

FRANCHINI, J.C.; BORKERT, C.M.; FERREIRA, M.M. \& GAUDÊNCIO, C.A. Alterações na fertilidade do solo em sistemas de rotação de culturas em semeadura direta. R. Bras. Ci. Solo, 24:459-467, 2000.

FRANCHINI, J.C.; CRISPINO, C.C.; SOUZA, R.A.; TORRES, E. \& HUNGRIA, M. Microbiological parameters as indicators of soil quality under various tillage and croprotation systems in southern Brazil. Soil Till. Res., 92:1829, 2007.

FRANCHINI, J.C.; GONZALEZ-VILA, F.J. \& RODRIGUEZ, J. Decomposition of plant residues used in no-tillage systems as revealed by flash pyrolysis. J. Anal. Appl. Pyrol., $62: 35-43,2002$

FRANCHINI, J.C.; HOFFMANN-CAMPO, C.B.; TORRES, E.; MIYAZAWA, M. \& PAVAN, M.A. Organic composition of green manures during growth and its effect on cation mobilization in an acid oxisol. Comm. Soil Sci. Plant Anal., 34:2045-2058, 2003.

GALLI-TERASAWA，L.V.; GLIENKE-BLANCO， C. \& HUNGRIA, M. Diversity of soybean rhizobial population adapted to a Cerrados soil. World J. Microbiol. Biotechnol., 17:933-939, 2003.

GRANGE, L. A análise polifásica na reclassificação genética de Rhizobium etli e o estudo da diversidade genética de isolados dos Cerrados brasileiros. Curitiba, Universidade Federal do Paraná, 2005. 152p. (Tese de Doutorado)

HUNGRIA, M. Características biológicas em solos manejados sob plantio direto. In: REUNIÓN DE LA RED LATINOAMERICANA DE AGRICULTURA CONSERVACIONISTA, 5., Florianópolis, 1999. Anais. Florianópolis, EPAGRI, 2000. CD-ROOM.

HUNGRIA, M. \& STACEY, G. Molecular signals exchanged between host plants and rhizobia: Basic aspects and potential application in agriculture. Soil Biol. Biochem., 29:819-830, 1997.

HUNGRIA, M.; CHUEIRE, L.M.O.; COCA, R.G. \& MEGÍAS, M. Preliminary characterization of fast growing strains isolated from soybean nodules in Brazil. Soil Biol. Biochem., 33:1349-1361, 2001.

HUNGRIA, M.; CHUEIRE, L.M.O.; MEGÍAS, M.; LAMRABET, Y.; PROBANZA, A.; GUTTIERREZ-MANERO, F.J. \& CAMPO, R.J. Genetic diversity of indigenous tropical fast-growing rhizobia isolated from soybean nodules. Plant Soil, 288:343-356, 2006a.
HUNGRIA, M.; FRANCHINI, J.C.; CAMPO, R.J. \& GRAHAM, P.H. The importance of nitrogen fixation to soybean cropping in South America. In: WERNER, D. \& NEWTON, W.E., eds. Nitrogen fixation in agriculture, forestry, ecology and the environment. Amsterdam, Springer, 2005. p.25-42.

HUNGRIA, M.; FRANCHINI, J.C.; CAMPO, R.J.; CRISPINO, C.C.; MORAES, J.Z.; SIBALDELLI, R.N.R.; MENDES, I.C. \& ARIHARA, J. Nitrogen nutrition of soybean in Brazil: Contributions of biological $\mathrm{N}_{2}$ fixation and of $\mathrm{N}$ fertilizer to grain yield. Can. J. Plant Sci., 86:927-939, 2006 b.

INSTITUTO AGRONÔMICO DO PARANÁ - IAPAR. Médias históricas das estações do IAPAR. Disponível em <http:// $200.201 .27 .14 / \mathrm{Site} / \mathrm{Sma} / \mathrm{Estacoes}$ IAPAR/ Estacoes_Parana.htm>. Acesso em 28 nov. 2006.

KASCHUK, G.; HUNGRIA, M.; ANDRADE, D.S. \& CAMPO, R.J. Genetic diversity of rhizobia associated with common bean (Phaseolus vulgaris L.) grown under no-tillage and conventional systems in Southern Brazil. Appl. Soil Ecol., 32:210-220, 2006a.

KASCHUK, G.; HUNGRIA, M.; SANTOS, J.C.P. \& BERTONJUNIOR, J.F. Differences in common bean rhizobial populations associated with soil tillage management in southern Brazil. Soil Till. Res., 87:205-217, 2006b.

LAGUERRE, G.; van BERKUM, P.; AMARGER, N. \& PRÉVOST, D. Genetic diversity of rhizobial symbionts isolated from legume species within the genera Astragalus, Oxitropys, and Onobrychis. Appl. Environ. Microbiol., 63:4748-4758, 1997.

LEONARDO, H.C.L. Indicadores de qualidade de solo e água para a avaliação do uso sustentável da microbacia hidrográfica do Rio Passo Cue, região oeste do estado do Paraná. Piracicaba, Escola Superior de Agricultura "Luiz de Queiroz", 2003. 131p.(Tese de Mestrado)

LOREAU, M.; NAEEM, S.; INCHAUSTI, P.; BENGTSSON, J.; GRIME, J.P.; HECTOR, A.; HOOPER, D.U.; HUSTON, M.A.; RAFFAELLI, D.; SCHMID, B.; TILMAN, D. \& WARDLE, D.A. Biodiversity and ecosystem functioning: current knowledge and future challenges. Science, 294:804-808, 2001.

MENDES, I.C.; HUNGRIA, M. \& VARGAS, M.A.T. Soybean response to starter nitrogen and Bradyrhizobium inoculation on a Cerrado oxisol under no-tillage and conventional tillage systems. R. Bras. Ci. Solo, 27:81-87, 2003a.

MENDES, I.C.; SOUZA, L.V.; RESCK, D.V.S. \& GOMES, A.C. Propriedades biológicas em agregados de um LE sob plantio convencional e direto no Cerrado. R. Bras. Ci. Solo, 27:435-443, 2003b.

MENNA, P.; HUNGRIA, M.; BARCELLOS, F.G.; BANGEL, E.V.; HESS, P.N. \& MARTÍNEZ-ROMERO, E. Molecular phylogeny based on the 16S rRNA gene a of elite rhizobial strains used in Brazilian commercial inoculants. Syst. Appl. Microbiol., 29:315-32, 2006. 
NOGUEIRA, M.A.; ALBINO, U.B.; BRANDÃO-JUNIOR, O.; BRAUN, G.; CRUZ, M.F.; DIAS, B.A.; DUARTE, R.T.D.; GIOPPO, N.M.R.; MENNA, P.; ORLANDI, J.M.; RAIMAN, RAMPAZO, L.G.L.; SANTOS, M.A.; SILVA, M.E.Z.; VIEIRA, F.P.; TOREZAN, J.M.D.; HUNGRIA, M. \& ANDRADE, G. Promising indicators for assessment of agroecosystems alteration among natural, reforested and agricultural land use in southern Brazil. Agric. Ecosyst. Environ., 115:237-247, 2006

PAVAN, M.A.; BLOCH, M.F.; ZEMPULSKI, H.D.; MIYAZAWA, M. \& ZOCOLER, D.C. Manual de análise química do solo e controle de qualidade. Londrina, Instituto Agronômico do Paraná, 1992. 40p. (IAPAR. Circular, 76).

PEIXOTO, R.S.; COUTINHO, H.L.C.; MADARI, B.; MACHADO, P.L.O.A.; RUMJANEK, N.G.; van ELSAS, J.D.; SELDIN, L. \& ROSADO, A.S. Soil aggregation and bacterial community structure as affected by tillage and cover cropping in Brazilian Cerrados. Soil Till. Res., 90:16-28, 2006.

SÁ, J.C.M.; CERRI, C.C.; DICK, W.A.; LAL, R.; VENSKEFILHO, S.P.; PICCOLO, M.C. \& FEIGL, B.E. Organic matter dynamics and carbon sequestration rates for a tillage chronosequence in a Brazilian oxisol. Soil Sci. Soc. Am. J., 65:1486-1499, 2001.

SANTOS, M.A.; VARGAS, M.A.T. \& HUNGRIA, M. Characterization of soybean Bradyrhizobium strains adapted to the Brazilian savannas. FEMS Microbiol. Ecol., 3:261-272, 1999 .

SARAIVA, O.F.; TORRES, E. \& FRANCHINI, J.C. Vinte anos de estudos da produtividade de soja submetida a sistemas de manejo do solo. In: CONGRESSO BRASILEIRO DE SOJA, 2., Foz do Iguaçu, 2002. Anais. Londrina, Embrapa Soja, 2002. p.135.

SAS INSTITUTE. Proprietary of software. Version 6. 4.ed. Cary, 1999

SHANNON, C.E. \& WEAVER, W. The mathematical theory of communication. Urbana, University Illinois Press, 1949 $117 \mathrm{p}$.

SHEN, T.J.; CHAO, A. \& LIN, J.F. Predicting the number of new species in further taxonomic sampling. Ecology, 84:798-804, 2003.

SIDIRAS, N. \& PAVAN, M. A influência do sistema de manejo do solo na temperatura do solo. R. Bras. Ci. Solo, 10:181$184,1986$.
SIDIRAS, N.; HENKLAIN, J.C. \& DERPSCH, R. Comparison of three different tillage systems with respect to aggregate stability, the soil and water conservation and the yields of soybean and wheat on an Oxisol. J. Agron. Crop Sci., 151:137-148, 1982.

SNEATH, P.H.A. \& SOKAL, R.R. Numerical taxonomy. San Francisco, Freeman, 1973. 573p.

STOTZKY, G. Soil as an environment for microbial life. In: van ELSAS, J.D.; TREVORS, J.T. \& WELLINGTON, E.M.H., eds. Modern soil microbiology. New York, Marcel Dekker, 1997. p.1-20.

TORRES, E. \& SARAIVA, O.F. Camadas de impedimento do solo em sistemas agrícolas com a soja. Londrina, EmbrapaCNPSo, 1999. 58p. (Embrapa-CNPSo. Circular Técnica, 23)

VANCE, E.D.; BROOKES, P.C. \& JENKINSON, D.S. An extraction method for measuring soil microbial biomass C. Soil Biol. Biochem., 19:703-707, 1987.

VINCENT, J.M. Manual for the practical study of root nodule bacteria. Oxford, Blackwell Scientific Publications, 1970. 164p. (International Biological Programme Handbook, 15)

VOSS, M. \& SIDIRAS, N. Nodulação da soja em plantio direto em comparação com plantio convencional. Pesq. Agropec. Bras., 20:775-782, 1985.

WARDLE, D.A. \& GHANI, A. A critique of the microbial metabolic quotient $\left(q \mathrm{CO}_{2}\right)$ as a bioindicator of disturbance and ecosystem development. Soil Biol. Biochem., 27:1601$1610,1995$.

WARDLE, D.A.; BONNER, K.J. \& NICHOLSON, K.S. Biodiversity and plant litter: an experimental evidence which does not support the view that enhanced species richness improves ecosystem function. Oikos, 79:247-258, 1997.

WARDLE, D.A.; YEATES, G.W.; NICHOLSON, K.S.; BONNER, K.I. \& WATSON, R.N. Response of soil microbial biomass dynamics, activity and plant litter decomposition to agricultural intensification over a sevenyear period. Soil Biol. Biochem., 31:1707-1720, 1999.

WEISBURG, W.G.; BARNS, S.M.; PELLETIER, D.A. \& LANE, D.J. 16S ribosomal DNA amplification for phylogenetic study. J. Bacteriol., 173:697-703, 1991.

WELBAUM, G.E.; STURZ, A.V.; DONG, Z. \& NOWAK, J. Managing soil microorganisms to improve productivity of agro-ecosystems. Crit. Rev. Plant Sci., 23:175-193, 2004. 